\title{
Reveal of household capabilities through financial literacy in community-based tourism
}

\author{
Magistyo P. Priambodo ${ }^{1}$, Nur Anita Yunikawati ${ }^{1 *}$, Emma Yunika Puspasari ${ }^{1}$, Sri \\ Handayani ${ }^{1}$, Marzanah A Jabbar ${ }^{2}$, and Fatima Sidi $^{2}$ \\ ${ }^{1}$ Faculty of Economics, Universitas Negeri Malang, East java, Indonesia \\ ${ }^{2}$ Faculty of Computer Science and Information Technology, Universiti Putra Malaysia, Malaysia
}

\begin{abstract}
The purpose of this study is to determine the extent of the condition of household financial literacy in community-based tourism which has continued to develop. Another thing that is also being studied knows the right way that households in the community-based tourism area are more empowered by increasing their financial literacy. In this research, the approach used is descriptive qualitative by conducting field studies to explore information from questionnaires given to respondents who are households in the community-based tourism area. Then conclude through purposive question to be able descripting real conclusions. The findings of this study indicate that not many households in community-based tourism are well literate with a low level of financial knowledge, so they are still unable to optimize the income they receive. There is a scheme from the government to help improve the welfare of the community in communitybased tourism areas with financial assistance and financial knowledge. This research only conducts studies in certain areas in the area around Junrejo municipality, Batu, East Java. The location is an area that has community groups that mostly have livelihoods as provider of tourism good and services.
\end{abstract}

\section{Introduction}

Over the past few years, financial literacy has been a particular concern for world researchers. This is due to the increased interest in learning financial literacy [1]; [2] specifically personal financial planning [3]; [4]; [5] to deal with the possibility of changes that occur in global financial markets. Research conducted by the OECD in 2012 and continued in 2015, the study aims to find out the level of financial literacy of the population in OECD countries. Based on this research shows that the financial literacy of 12 OECD countries is still low [6]. In addition, based on the OECD survey report [7] it was found that in the G20 countries only half the adults achieved the minimum score, at least six out of

\footnotetext{
Corresponding author: nur.anita.fe@um.ac.id
} 
nine people to improve their basic financial abilities [8]. One of the causes of a person's low financial literacy is due to lack of one's ability to make personal financial planning [8] as seen in China [3] which in the study S. Yu argues that increasing the basic financial ability will able to support investment performance. This is not without reason because a person's basic financial abilities influence one's financial decisions [9]; [10]; [11]. Lusardi [9] stated in his research that the link between numerical ability and financial decision of the American population, he further suggested to pay special attention to the basic ability of financial nature which is numerical because it would be beneficial to improve one's ability to make rational decisions to use their money. Lusardi's opinion is reinforced by Calcagno and Monticone's research [10] that investors with low financial ability are advised to consult more deeply with investor advisors, but what happens is the opposite is true for investors who have low financial literacy levels, do not consult investment advisors but they tend to give delegations to investment advisors to make their portfolio decisions. Other facts were also stated by Stolper and Walter [11] in Germany that their hopes to evaluate financial education which turned out to be less effective in the field were applied, in addition they argued that using the services of individual financial advisors to improve financial literacy. So that financial literacy studies are not only important for individual financial decisions but also at the business and entrepreneurial level.

In Indonesia, a survey conducted by the Financial Services Authority (OJK) [12] in 2019 showed that $38.03 \%$ of Indonesia's population had good financial literacy categories. This number has increased compared to a survey conducted in 2016 which amounted to $29.7 \%$ of Indonesia's population has very good financial literacy. Thus in the last three years there was an increase in the population's financial literacy of $8.33 \%$. Based on regional strata, for urban financial literacy index reached $41.41 \%$ and financial inclusion of urban communities amounted to $83.60 \%$, while the literacy index and financial inclusion of rural communities were $34.53 \%$ and $68.49 \%$. The survey results also showed that based on gender literacy index and financial inclusion of men were $39.94 \%$ and $77.24 \%$, relatively higher than women at $36.13 \%$ and $75.15 \%$. Despite the increase in the financial literacy index in general it can be said that as many as $70 \%$ of Indonesia's population still do not have financial literacy properly. Banking products still dominate the financial literacy of the Indonesian population, this has proven to be a permanent banking succession and is increasingly popular among the public than other non-banking products or sectors. So financial literacy should be studied by individuals, business people, and government [13].

East Java is one of the provinces in Indonesia which has a financial level in low category. The OJK survey [14] in 2016 stated that the level of financial literacy of East Java's population of $35.6 \%$ had good financial literacy. There are three big cities contributing financial literacy in East Java Province, namely Surabaya, Jember and Malang. Malang Raya has a financial literacy rate of 33.9\%. The term Malang Raya consists of 3 regions which are Malang City, Malang Regency and Batu City. Batu City as one part of Malang Raya also plays a role in the economic growth in Malang Raya. Batu City is known as the Batu Tourism Region, it is very clear that its main economic support comes from tourism. Most of the residents earn a living in tourism activity. Therefore, financial literacy in the business community is very important to support economic growth in Batu City. The purpose of writing this article is to identify the financial literacy of the tourism business community in the Junrejo municipal, Batu City. It is very interesting to expose how Community based Tourism could be developed in line with increasing financial literacy among its human resources. 


\section{Method}

This study uses qualitative research methods with a case study approach. Bazan [18] stated that qualitative case study research provides a strong understanding of the phenomena that arise from the complexity associated with interpersonal activities in a broad social context. A case study can provide a rich collection of data so that researchers can directly observe and conduct interviews with informants related to the phenomenon [19]; [20]; [21]. The phenomenon in this study is the level of financial literacy of the community based tourism businesses in the Junrejo District. The research locations we chose were villages in the Junrejo District of Batu City. The reason for choosing a research location in the Junrejo District of Batu City is because it represents the criteria that we set, because the mostly of the peoples living as entrepreneurs as well as cultural and economic elements.

The types of data in this study are primary data and secondary data. Primary data includes basic financial capabilities, namely knowledge of financial service institutions, confidence in financial service institutions, knowledge of banking product services and products of non-bank financial institutions, ability to calculate personal finance, financial information, financial management, financial budgeting, and financial security. The instruments used in our primary data sources adopted from OECD [22] and OJK [14]. Whereas secondary data includes OECD publications, OJK publications, Bank Indonesia publications, BPS East Java, BPS Batu City and secondary data from the Junrejo district government.

In qualitative research, data collection is carried out in natural settings, primary data sources, and data collection techniques using triangulation / combination. While the data obtained through; Focus Group Discussion (FGD), observation, survey, in-depth interview and document analysis. We determined 12 informants from Focus Group Discussion (FGD) participants consisting of 6 male and 6 female. Participants have different characteristics both gender, age, income level, and type of livelihood. We communicated with participants, in-depth interviews and FGDs conducted during July-September. Data collection conducted by location-based researchers consists of three stages: stage 1 (months 1-2) participant observation observing the scale of financial literacy; stage 2 (months 3-4) focus groups and stage 3 (months 5) semi-structured interviews.

\section{Result and Discussion}

Based on the results of in-depth interviews and field observations to the informant which were carried out in stages, known real conditions were revealed and became the study material of this research. The following are the identities of the respondents involved,

Table 1. Participants identities and data

\begin{tabular}{|c|l|c|l|l|l|c|}
\hline Participant & sex & age & education & \multicolumn{1}{|c|}{ Occupation } & Income/month & In debt \\
\hline Participant 1 & male & 22 & Vocational & Coffee Shop & IDR 5.000.000 & Yes \\
\hline Participant 2 & male & 56 & Bachelor & $\begin{array}{l}\text { Guesthouse } \\
\text { Owner }\end{array}$ & $\begin{array}{l}\text { IDR } \\
10.000 .000\end{array}$ & Yes \\
\hline Participant 3 & male & 52 & Bachelor & $\begin{array}{l}\text { Fish Pond } \\
\text { Owner }\end{array}$ & IDR 6.000.000 & Yes \\
\hline Participant 4 & female & 49 & Vocational & Culinary & $\begin{array}{l}\text { IDR } \\
13.000 .000\end{array}$ & Yes \\
\hline
\end{tabular}




\begin{tabular}{|c|c|c|c|c|c|c|}
\hline Participant 5 & female & 51 & $\begin{array}{l}\text { Senior } \\
\text { High } \\
\text { School }\end{array}$ & Convection & IDR 750.000 & No \\
\hline Participant 6 & female & 48 & $\begin{array}{l}\text { Senior } \\
\text { High } \\
\text { School }\end{array}$ & Farmer & IDR 3.000 .000 & Yes \\
\hline Participant 7 & female & 45 & Bachelor & $\begin{array}{l}\text { Government } \\
\text { Agent }\end{array}$ & IDR 4.000.000 & No \\
\hline Participant 8 & male & 38 & $\begin{array}{l}\text { Senior } \\
\text { High } \\
\text { School }\end{array}$ & Flower shop & IDR 3.000.000 & Yes \\
\hline Participant 9 & male & 42 & Bachelor & Souvenir Shop & $\begin{array}{l}\text { IDR } \\
25.000 .000\end{array}$ & Yes \\
\hline Participant10 & male & 50 & $\begin{array}{l}\text { Senior } \\
\text { High } \\
\text { School }\end{array}$ & Fruit Farmer & IDR 7.000 .000 & Yes \\
\hline Participant11 & female & 57 & $\begin{array}{l}\text { Senior } \\
\text { High } \\
\text { School }\end{array}$ & Souvenir Shop & IDR 2.000.000 & No \\
\hline Participant12 & female & 48 & $\begin{array}{l}\text { Senior } \\
\text { High } \\
\text { School }\end{array}$ & $\begin{array}{l}\text { Guesthouse } \\
\text { Owner }\end{array}$ & $\begin{array}{l}\text { IDR } \\
12.000 .000\end{array}$ & Yes \\
\hline
\end{tabular}

12 of our interview participants gave code P1 for participant 1, P2 for participant 2 and so on until P12 as the 12 participant, and demographic data is available in the table above table 1. Among the 12 participants we interviewed consisted of 6 male participants and 6 female participants. The average age of productive age is 50 years, the youngest age of participants is 22 years and the oldest age is 57 years. The highest education is undergraduate and the lowest education is high school. The business sectors of the participants varied consisting of business services, trade and production, while only 1 participant worked as a government employee. The average income is in accordance with the minimum wage, the highest income is the owner of a souvenir business center, which is IDR 25,000,000 per month and the lowest is the knitting business that has an income of IDR 750,000 per month. Debt ownership almost most participants have debt, only 3 participants out of 12 participants who have no debt.

Table 2. Question Guidance

\begin{tabular}{|c|l|}
\hline No & \multicolumn{1}{|c|}{ Questions Grid } \\
\hline 1 & Knowledge of financial service institutions \\
\hline 2 & Confidence in financial institutions \\
\hline 3 & $\begin{array}{l}\text { Knowledge of banking product services and products of non-bank financial } \\
\text { institutions }\end{array}$ \\
\hline 4 & The ability to calculate personal finances \\
\hline 5 & How to obtain financial information \\
\hline 6 & Personal and family financial management \\
\hline 7 & Financial budgeting \\
\hline 8 & Financial security \\
\hline
\end{tabular}


Question number 1: Do you know of a financial service institution? If you know what the financial institutions are! And do you have an account at the financial institution that you mentioned earlier?

All participants answered the question with the same answer, which is they knew the financial institution. However, when participants were asked to mention financial institutions 9 out of 12 participants could not mention more than 3 financial service institutions, meaning that only 3 participants could mention financial service institutions more than 3 financial service institutions. The average participant mentioned banks, pawnshops, cooperatives because the most popular according to them only banks. This can be seen from the interview snippet below.

"...I only know banks, like BRI, BNI and that's what I often see on the road" (P3)

"...Banks, cooperatives enter or not? Looks like a cooperative. Continue to pawn shops, because I often go to pawnshops"(P5)

"...The bank is certain, briefly there are other financial service institutions huh?" (P8)

Based on the interview excerpt that the bank is a financial service institution that is very popular among the public, both urban and rural. In aggregate, Indonesia is $98 \%$ bank literate based on a 2016 national survey. It is also seen in the results of this study that $100 \%$ of participants are banking literate, and have accounts in banks. In line with Shah's research [23] states that banks are the only institution finance which is already widely used by the population of India. Another study states that financial literacy significantly determines savings patterns with formal and informal financial institutions; however, income only drives the frequency of informal savings [2]. Therefore banks must provide maximum services so that even villagers can enjoy banking product services.

Question number 2: Why do you use banking products?

The average results of the answers to these questions are due to a sense of security and some respondents expressed the reason for the ease of loan or credit facilities from banks

"...If I save in a bank, it's safer than you must save it at home" (P8)

"... Of course the safety factor, miss, understand if it is stored at home I am worried that something will happen" (P9)

"...I can buy this house and the motorbike that I made, which also uses the existing credit facility at your bank" (P7)

"...I started this small business and at first also borrowed money from the bank; you know ... you don't have much funding" (P12)

Question number 3: Do you know about financial service institution product services? Yes, mention it.

All participants answered knowing the products of financial service institutions. However, when asked to mention banking service products, most of the participants answered savings, and only a small portion answered savings and deposits. Whereas the products of financial service institutions depend on the financial service institutions. For example, banks have banking products such as: savings, deposits, current accounts, transfers, credit, and electronic money. While insurance financial institutions include: life insurance, vehicle insurance, home insurance and so forth. In addition, other non-bank financial service products such as capital markets, financial institutions, venture capital, pension funds, and pawnshops. The following are the results of interviews.

"...As far as I know, if you go to the bank, you will save money" (P9) 
"...Saving and credit if going to the bank" (P4)

Question number 4: Basic calculation skills.

At this stage participants are given 4 simple questions that are used to determine the basic ability to count. These questions are:

a. If 5 siblings are given IDR 100,000, - and they have to share the money equally, how much money does each receive?

b. If the five siblings have to wait for one year to get their share of money, assuming the same inflation rate, then they will be able to buy: (more / as much / less / less / depending on the items purchased)

c. If you save IDR 100,000 , with an interest rate of $2 \%$ per year, what is your total savings at the end of the first year? (assuming you do not make deposits or withdraw money)

d. Do you believe that investing with large profits tends to have a high risk?

Table 3. Answers to Counting Ability

\begin{tabular}{|l|c|l|}
\hline Partispant & Correct Answer & Percentage \\
\hline Partisipant 1 & 1 & $25 \%$ \\
\hline Partisipant 2 & 1 & $25 \%$ \\
\hline Partisipant 3 & 4 & $100 \%$ \\
\hline Partisipant 4 & 2 & $50 \%$ \\
\hline Partisipant 5 & 4 & $100 \%$ \\
\hline Partisipant 6 & 1 & $25 \%$ \\
\hline Partisipant 7 & 3 & $75 \%$ \\
\hline Partisipant 8 & 2 & $50 \%$ \\
\hline Partisipant 9 & 4 & $100 \%$ \\
\hline Partisipant 10 & 2 & $50 \%$ \\
\hline Partisipant 11 & 2 & $50 \%$ \\
\hline Partisipant 12 & 2 & $50 \%$ \\
\hline
\end{tabular}

Based on table 3 above, it can be seen that from 12 participants answering all questions correctly, only 3 participants. One participant answered 3 correct answers. Five participants answered correctly 2 questions and as many as 3 participants answered correctly 1 question. So it can be concluded that the average participant can only correctly answer two questions. So in the case of simple financial calculations included in the medium category.

Question number 5: where did you get financial information?

The answers given to this question vary greatly; from TV commercials, Instagram, YouTube, from family (husband / wife), friends and so on. This can be seen in the interview below:

"...I know financial information from TV, YouTube, and my wife" (P2)

"...Now we can easily get information such as YouTube, Instagram is widely used to get various information" (P9)

"...I rarely watch TV but sometimes get info from newspapers that are usually subscribed to by the office where I work" (P7)

Technological developments also affect a person's life, the rise of the internet to facilitate communication and information. This also becomes more value for the world of banking and non-bank financial institutions to expand information to the public about their banking products. If the information provided is very informative and on target it is not impossible that it will increase one's financial literacy and they easily digest the contents of the information provided. In line with Gabor's research [24] that the increasing importance 
of digital-based financial inclusion as a form of organizing development interventions through a network of state institutions, international development organizations, philanthropic investments, and fintech companies.

Question number 6: Explain the purpose of having money?

The answer to this question is very broad, but we conclude that the purpose of having money for participants is to meet basic daily needs, maintain life, pay for children's education costs, prepare for old age, develop businesses, improve quality of life, provide emergency funds, and meet health costs. This can be seen from the results of the interview below:

"...Yes, to be realistic, that we have money for daily needs" (P1)

"...What is certain for children's school is the most important" (P5)

"...In my opinion what is certain is that the basic needs for clothing, food and shelter are basic needs, right? Then the most important thing is preparing old age, or for example there is a sudden need "(P9)

Question number 7 is: How do you meet these financial goals?The answers from the participants were very diverse but we concluded that how to meet financial goals include: saving, preparing financial plans, working, reducing expenses, developing independent businesses, looking for loans, making investments, and looking for alternative debt. This can be seen from the following interview footage:

"... Saving regularly, especially I'm a civil servant I can only save, if not to use other banking products, I haven't" (P7)

"...I have to be smart to manage my money, so if I have a restaurant, I have to be able to differentiate between my money and my cafetaria. If there are advantages, then save, if not, then no. Moreover, my income is not certain every day, it is not always crowded, but also my stall, if the inter-clever gap regulates money, it's really bad, sis "(P4)

"...I set up this shop I thought that this was my investment, so if I was asked how to meet these financial goals I would answer, yes, investment. After all, investment is not merely in the capital market, right? Like me, this can already be said as an investment "(P9)

"...I am used to saving money, and there is a new habit that I have adopted, which is to collect money and then if it's quite a lot I will buy gold. The advantage that you can get if you buy gold is that I am not hypocritical, can I use gold, then if there is a sudden need, for example, a family is sick or there is a disaster, just sell it. There is a lot of gold market, so I'm comfortable if I can have as many believers as possible. It's different if I buy land, I don't sell land easily at any time "(P12)

"...Ideally saving or investing, but if it is not enough capital for me to add debt it can be a good solution" (P1)

Question number 8 is: do you always compile a financial budget? If yes, is it arranged in detail or just an outline?

All participants answered yes, then regarding the answers to the questions compiled a detailed budget or a magnitude plan of 10 people out of 12 respondents answered only a big plan. This means that only 2 participants made detailed budget plans. This can be seen from the interview below:

"...I rarely make detailed plans, because the money is just barely enough to want to write financial planning. I don't think it's even made a plan but the money isn't there "(P1) 
"...Make it sis but it's only a big plan, for example for college children are the main thing" (P5)

"...For the budget plan, but it's not complete, I only think about this year. What do you want to do for the new magnitude, I need to detail how much needs are spent" (P7)

"...For me planning is important, so I make detailed plans every month" (P9)

Question number 9: Are you fully committed to the financial planning that has been made?

The participants' answers to this question contained 6 participants answered having high commitment and 6 other participants answering sometimes having commitments. This can be seen from the results of the interview below:

"...If you have to make a big commitment with the plan that I have made, that's the purpose of planning so that I don't turn left and right and spend my money on consumptive things."

"...For me commitment is important so as much as possible I will keep the financial planning commitments that I have made"

"...Commitment is important, with a note that if there is money, but if there is no money, how? Can you eat, it's already good, you"

"...I really want to be committed, but sometimes in the middle of the road there is a sudden need for the results of the money that I collected, I used to use it to cover my shortcomings. Well, if I am out of debt, think I am better off using that money first "

Question number 10: If you have more money, what is the money?

The answers to these questions are very diverse, but we summarize the participants' answers, namely: saving, buying property, buying a vehicle, buying deposits, buying life insurance, buying gold, education insurance. This can be seen from the interview excerpt below.

"...If I have more money, I want to save the money or buy gold"

"...I will buy more land to increase my agricultural yield"

"...I will buy a new car, I will save the rest"

"...Insurance is more important in my opinion, both life insurance and education insurance for my child"

Question number 11: How do you meet the old age?

Like the previous question, the answers to these questions are very diverse but we summarize the participant's answers which is savings, keep working, selling non-financial assets (jewelry or property), pension funds, dependent on children, and deposits. This can be seen from the results of the interview below:

"...Yes, I registered myself in the pension fund. So later I won't have to bother to just take my pension"

"...I have a special savings old age"

"...Right now I am buying some land and gold. I hope that if it is old, it can be sold."

"...I do not have anything but I send my children to college hope that later when I am old those who support me"

Based on the results of in reality, development today the study of this field seeks to explain the differences in financial inclusion and its financial practices, not by pointing to eternal intrinsic values, but rather by referring to the entire map of financial literacy relations and economic prosperity. Therefore, the scientific field of study is open to accommodate all scientific aspirations to see the phenomenon of financial literacy faced by the people of Junrejo Batu. So the financial literacy study is expected to be able to build a framework and try to locate or rediscover the essence of public trust in banking programs 
up to now been forgotten or forgotten. Until now, financial literacy studies have clearly defined domains. It thrives on boundaries and meetings on various discourses that have been institutionalized, in the study of economics. The aim is to find out how the financial literacy of the Junrejo village community as an economic predictor in essence is related to the understanding of banking products as well as their relationship to the economic relations being cultivated by the Junrejo people. Having revealed the reality in the previous section, it would be more appropriate if this study would more closely examine the course of the presence of the field of financial science in the modern economic arena and its development until the development of financial literacy studies. The dynamics of financial literacy studies have had an important influence in understanding the economic entities of the Junrejo Batu village community. Studying financial literacy (FL) for the people of Junrejo is the courage to redefine the meaning of finance itself as a process of meaning in people's lives. Understanding of finance for the community is not seen as a generic thing which is a guideline which is derived or inherited, but rather is seen as a differential inclusion that is negotiated in the overall economic and social interaction.

The focus of this study, examines the meaning of the community towards financial inclusion that specifically wants to answer the meaning behind the meaning of financial literacy in the Junrejo region community. Financial literacy for the people of the municipality of Junrejo sometimes does not only rely on the ability of an effective campaign. However, cognitive abilities, trust and understanding of financial literacy paved the expansion of various financial related programs to villages that were not touched by financial institutions. As for operations that are not on target, high interest is also one of the reasons why the people of Junrejo region have not been able to switch to formal financial institutions.

Financial Literacy Processes

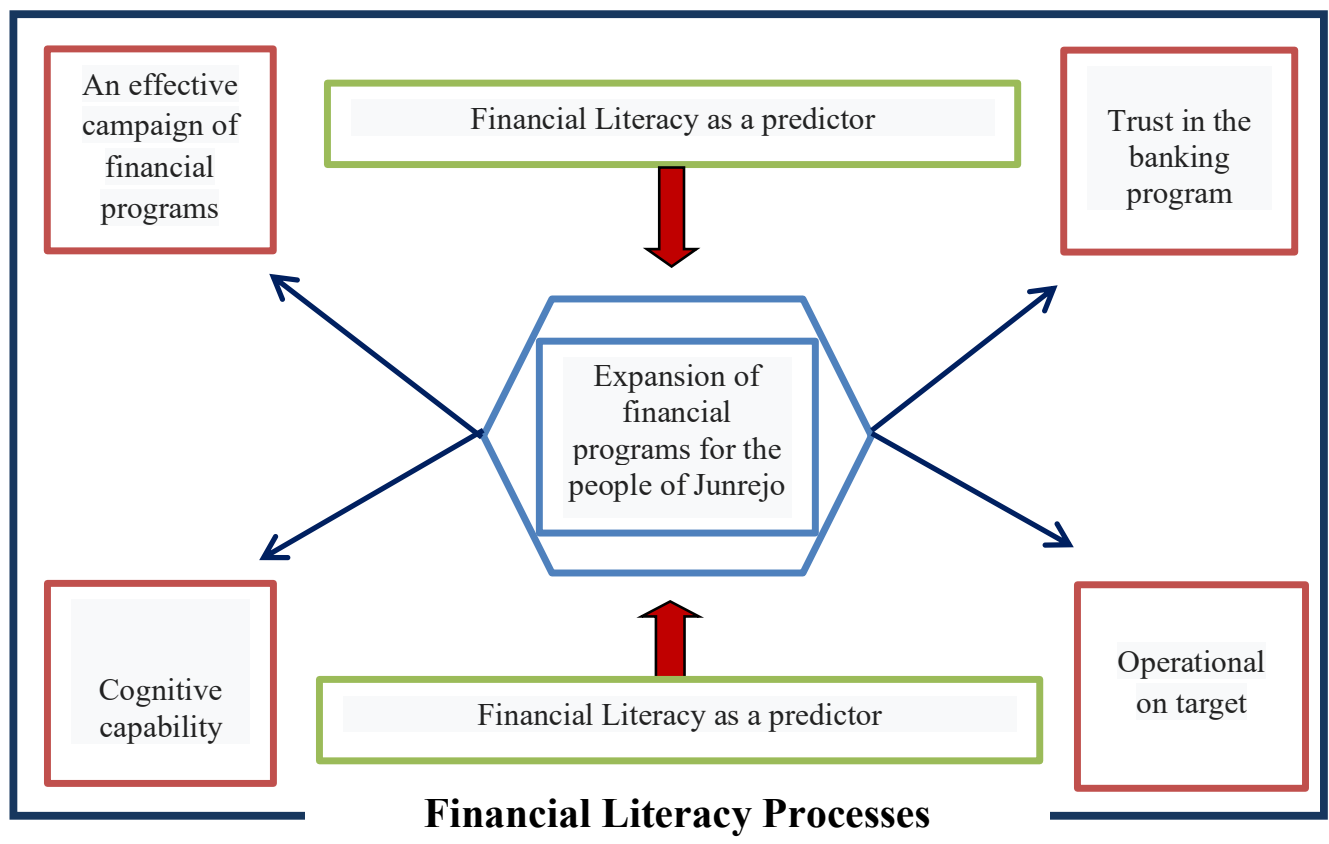


Fig. 1 Financial Literacy framework

\section{Conclusion}

This article analyzes the importance of financial literacy studies for the people of the village of Junrejo Batu in relation to the problem of micro and macro economic growth, to be material so that financial literacy is seen in an appropriate context. It is hoped here that awareness of the importance of financial knowledge and behavior is not only seen from the perspective of individuals alone. From a broader perspective, financial literacy can also have an impact on the regional economy in Batu, in terms of the welfare of its people and also the progress of its financial institutions. Departing from some of the situations narrated in the previous section, building the financial literacy of the Junrejo village community is a collaborative effort of several components that exist in the village community, synergizing and moving together in terms of developing, increasing the financial inclusion of the community with the financial behavior of the community.

The fundamental changes that are taking place and will take place in the society in which we define this field of research, require adjustments in the workings of economic and cultural literacy research. Conventional methods must be modified so that financial literacy research is not trapped again in the category of research that is 'non-novelty' and 'exotic'. This is also given the economic position as a scientific discipline that provides the basis for the development and testing of theories, so that its success records the nature and the nature of a phenomenon will influence in further studies.

Financial literacy for the people of Junrejo Batu sometimes does not only rely on the ability of effective campaigns to expand banking programs. Cognitive ability, trust and understanding of financial literacy have accelerated the expansion of various banking programs in the village of Junrejo Batu. There is the most important point found, which is the Operations that are not on target, the high interest rate is one of the reasons why the Junrejo community cannot switch to banking products. Based on the results of case studies that have been carried out, it shows that financial literacy is a strong predictor of demand for banking financial services and products.

\section{References}

1. T. Wright, Financial Literacy and the Digital Divide, in Proceedings of Global Learn 2019, (2019)

2. O. M. Adetunji dan O. David-West, J. Int. Dev., (2019)

3. S. Xu, Z. Xiong, dan L. Jiao, Transform. Bus. Econ., (2019)

4. H. Ismanto, H. Muharam, A. Widiastuti, I. R. D. Pangestuti, dan F. Rofiq, The impact of financial literacy and financial attitude on income level and good credit payment, in Proceedings of the 33rd International Business Information Management Association Conference, IBIMA 2019: Education Excellence and Innovation Management through Vision 2020, (2019)

5. A. Caplinska dan A. Ohotina, Entrep. Sustain. Issues, (2019)

6. OECD, OECD Economic Outlook, Volume 2019 Issue 1. (2019)

7. OECD, "G20/OECD Policy Guidance Financial Consumer Protection Approaches in the Digital Age," (2018)

8. Organisation for Economic and Cooperation and Development, "OECD/INFE international survey of adult financial literacy competencies," OECD, (2016) 
9. A. Lusardi, Numeracy, Financial Literacy, and Financial Decision-Making, Numeracy, (2012)

10. R. Calcagno dan C. Monticone, J. Bank. Financ., (2015)

11. O. A. Stolper dan A. Walter, J. Bus. Econ 87, 581-643 (2017)

12. S. Ojk, I. Literasi, D. A. N. Inklusi, dan K. Meningkat, "Sp 58/dhms/ojk/xi/2019," no. November, hal. 29600000, (2019)

13. J. Titko, G. Ciemleja, dan N. Lace, Procedia - Soc. Behav. Sci, (2015)

14. OJK, National Literacy and Financial Inclusion Survey 2016, (2016)

15. S. J. Huston, J. Consum. Aff Vol 44 (2), 296-316 (2010)

16. D. Fernandes, J. G. Lynch, dan R. G. Netemeyer, Manage. Sci, (2014)

17. A. Lusardi, O. S. Mitchell, dan V. Curto, J. Consum. Aff., (2010)

18. B. Yazan dan I. C. O. De Vasconcelos, Meta Aval, (2016)

19. R. K. Yin dan R. K.Yin, Qualitative Research from Start to Finish, (2011)

20. T. Hollweck, "Robert K. Yin. Can. J. Progr. Eval, (2016)

21. R. K. Yin, Understanding qualitative research. (2018)

22. OECD, OECD / INFE Toolkit to measure financial literacy and Financial Inclusion: Guidance, Core Questionnaire and Supplementary Questions, (Financ, Aff. Div, 2013)

23. P. Shah dan M. Dubhashi, Chanakya Int. J. Bus. Res Vol 1(1), 37-48 (2015)

24. D. Gabor dan S. Brooks, New Polit. Econ, (2017) 